\title{
EDITORIAL
}

\section{IMPACT OF HIV/AIDS ON EDUCATION IN THE SUB-SAHARAN AFRICA}

HIV /AIDS mark a severe development crisis in sub-Saharan Africa, which remains by far the worst affected region in the world. Approximately 3.5 million new infections occurred in 2001, bringing to 28.5 million the total number of people living with HIV/ AIDS in this region. The total number of orphaned children in the region at the time was estimated to be 11 million(1). The bulk of new AIDS cases are among young people of school going age, aged 15-25 years(2). Projections under conservative assumptions suggests that the toll of AIDS in sub-Saharan Africa will reach five million by 2010(3). Education and training are critical for long term development. The extent to which schools and other educational institutions are able to continue functioning will influence how well societies eventually recover from the AIDS epidemic(l). The provision and growth of quality education is directly linked to positive economic development, emancipation and health dividends(2). HIV/AIDS impacts negatively on the following aspects of education $(2,4)$. (i) the demand for education, (ii) the supply of education and, (iii) the quality and management of education.

A decline in school enrolment has been observed in many sub-Saharan countries and is widely reported(1,2,5). Contributing factors include removal of children from school to care for parents and family members, inability to afford school fees and other school expenses, AIDS related infertility and a decline in birth rate, leading to fewer children and early deaths of children due to HIV infection. This stagnation and or decline in school enrolment has also been observed in Swaziland(6), Botswana(7), South Africa(8), Zambia(9)and Malawi(10) among the countries in subSaharan Africa.

HIV/AIDS has significantly affected the ability of educational systems in sub-Saharan Africa to supply and manage quality education $(1,2,4)$. This has been mainly through affecting the management and supply of education by diminished supply of teachers due to mortality. In Zambia, the number of teachers dying from AIDS is greater than the output from the teachers training colleges(11), while in Kenya, it has been reported that 20-30 teachers die monthly, in one of the districts, from AIDS, with 200 dying monthly in the whole country from AIDS(2). The supply of education can also be hampered by declining productivity of teachers due to frequent absenteeism because of illness, care of the ill family members or in funeral attendances leading to severe decline in learner/teacher ratio and reduced teaching due to slow or non-replacement of teachers who have died from AIDS. Education budget has also been adversely affected by training of additional teachers, reduced availability of family resources and by double payments of off-duty teachers and their replacements.
Emotional stress of teachers and learners is also high through increased incidence of HIV and death due to AIDS among colleagues and relatives $(2,12)$. This significantly affects the quality of learning. Other factors that must be considered include devalued standing status of teachers in the community through community perception of teachers as contributors to the spread of AIDS, perception of educational institutions as risky environment for sexual relationship between learners, and between learners and teachers(13), and decline in standards of management, administration and financial control of educational institutions due to loss of human resources.

The impact of HIV/AIDS in the education sector is no doubt grave. The consequences are far reaching. Since the education sector is a leading employer in all countries. Education determines the future economy of any country. The challenge is to find ways to manage the situation and turn what is now seen as a high risk environment into an effective instrument to combat ignorance and motivate sustainable behaviour change. Some suggested interventions include, but are not limited to $(2,13,14)$ recognizing that HIV/AIDS is a serious disease with serious consequences to the education sector. All related issues should be documented, discussed and communicated from the highest level. Enactment of enabling policies and review of existing policies and regulations, and identification and changing of those items that are in conflict with effective response in the current policies is an urgent need. Also important is the empowerment of teachers and students by creating an environment in which life skills and personal choice can be taught. In Kenya(15), teaching of HIV/AIDS in schools is now official policy, but only 6000 out of 240,000 teachers have been trained in HIV/AIDS curriculum. Other considerations in managing the impact are reducing the risk of HIV transmission in schools by ensuring accountable administration, implementable code of conduct, appropriate disciplinary measures and other measures that will ensure responsible behaviour surveillance to monitor and record progress of the pandemic with respect to key education issues; operational collaboration and partnership with the health sector, NGOs and other sectors involved with HIV/ AIDS; creation and development of resource centers to avail educational materials, facilitate distribution of materials, library access and educational support; availing accessible testing and counseling centers. This may enable establishment of prevalence data rates in the staff and in the classrooms; support for orphans in a creative manner; training more teachers to replace those that have died; enrichment and modifications of curricular to promote choice and sustainable behaviour 
change; promotion of positive attitude to those infected or affected by HIV; and sharing of experiences and information locally, regionally and internationally to facilitate effective collective strategic plans, developments of early warning signs and action plans.

In conclusion, the challenges posed by HIV/AIDS to the education sector in sub-Saharan Africa are not only daunting but also intimidating. The students and their teachers should be equipped with survival and coping skills. The education sector in sub-Saharan Africa should be rescued from impending doom and total collapse by putting in place resources that will ensure continuity of quality education.

G. O. Oyoo, MBChB, MMed, FACR, Humphrey Fellowship Programme, Tulane University, Health Sciences Centre, School of Public Health and Tropical Medicine, Department of International Health and Development, Deming Pavillion, Apartment 323, 204 South Saratoga Street, New Orleanss, LA 70112, USA.

\section{REFERENCES}

1. AIDS epidemic update, UNAIDS. December 2002.

2. Gachuhi, D .The impact of HIV/AIDSon the education systems in the eastern and southern Africa region and the response of education systems to HIV/AIDS; Life Skills programme. 1999 UNESCO report(www.unesco.org)

3. Vandewalle, E. The social impact of AIDS in Sub-Saharan Africa. Mid bank quarterly. 62, 1999; 1:10-32, .

4. Barnett, T. and Whiteside, A. Government and governance:
In Aids the twenty first century-disease and globalization pages 295-316. Palgrave Macmillan. 2003 Edition.

5. Johnstone, T. et al. A profile of adolescent orphans. Population communication Africa, Nairobi. 1999.

6. Ministry of Education, Swaziland. Impact of HIV/AIDS on education sector in Swaziland. Ministry of education report. 2000 report. www.zimaids.co.zw.

7. Government of Botswana, The impact of HIV/AIDS on primary and secondary education in Botswana: Developing a strategic response, AFID. 2002.

8. Badcock-Walters, P. The impact of HIV/AIDS on education in Kwa- Zulu Natal. Durban Kzndel provincial educational unit report 2001. www.und.ac.za/und/heard/publications/ educationimpact june2000.

9. Hunters, S. Orphan programming in Zambia: a strategy for very young children in Zambia. Unesco. 1998 report, Lusaka. www.unesco.org.

10. Kadzamira, et al. The impact of HIV/AIDS on primary and secondary schooling in Malawi; developing a comprehensive strategy, UNESCO report, 2001

11. Kelly, M. The inclusion of an HIV/AIDS component in BESSIP, Lusaka. 1998.

12. Baggaley, R. et al. HIV stress among primary school teachers in Zambia. Bulletin of the world health organization. 1999; 77:284-287.

13. Health Economics and HIV/AIDS Research Division of the University of Natal (HEARD) Impact assessment of HIV/ AIDS on Namibia's education sector, UNESCO 2003 report www.und.ac.za/und/heard/mtf/TORhtm.

14. Barasa, C. HIV/AIDS and education in Uganda, Uganda education sector survey. 1997. www.sahims.net.

15. Ministry of Education, Kenya. Country HIV/AIDS report: Kenya rapid education November 2002. www.schoolsandhealth.org. 